\title{
Przemieszczanie się centrum Mławy w historii jej rozwoju - znaczenie centrotwórcze stacji kolejowej Mława Miasto
}

\section{Izabela Sobierajska, Teresa Wyszyńska}

\begin{abstract}
STRESZCZENIE
Celem niniejszego opracowania jest przedstawienie współczesnych problemów zagospodarowania i funkcjonowania centrum usługowego Mławy, ze szczególnym uwzględnieniem historii rozwoju i przemieszczania się funkcji centrotwórczych w mieście, powiązanych z wielowiekową tradycją handlową.

Pierwotne centrum, czyli lokacyjny rynek z końca XV w. pełnił główną rolę centrotwórczą do czasów II wojny światowej. Już od końca XIX w. centrum rozrastało się w kierunku zachodnim. Druga połowa XX w. to szybki rozwój miasta i powstawanie obiektów o znaczeniu centrotwórczym w zachodniej części śródmieścia.

Początek XXI w. to realizacje dużych obiektów handlowych, uzupełniających dotychczasowy program centrum i wzmacniających jego układ na osi wschód-zachód.

Najnowsze plany dotyczące rozwoju miasta, wykorzystujące wzrastające, miastotwórcze znaczenie stacji, przewidują budowę nowego obiektu handlu wielkopowierzchniowego w rejonie stacji Mława Miasto. Drugim, podobnym zespołem, stanie się rozbudowany obiekt handlowy funkcjonujący na północny wschód od rynku. Po realizacji staną się one wyraźnymi krańcami pasmowego centrum miejskiego.

Artykuł zawiera ogólne sugestie proponowanych działań wzmacniających przede wszystkim układ powiązań pieszych oraz przestrzeni reprezentacyjnych, możliwy do wytworzenia w ramach docelowego układu centrum.

Słowa kluczowe: Mława, rynek miejski, Stary Rynek, Wólka, stacja Mława Miasto, ratusz
\end{abstract}

\section{Wprowadzenie}

Obecnie Mława to miasto powiatowe położone w pobliżu północnej granicy województwa mazowieckiego. Ludność miasta liczy około 31 tysięcy mieszkańców. Jest to jeden z nielicznych przypadków w Polsce, gdzie w ciągu zarówno ostatnich 10 jak i 5 lat zanotowano w mieście wzrost liczby mieszkańców, co prawda niewielki, ale wzrost.

Najstarsze ślady osadnictwa w Mławie, datowane nawet na przełomie XIII i XIV w., odkryto w rejonie obecnego rynku oraz na przedmieściach Kozielsk i Zabrody. W rejonie obecnego Starego Rynku przed rokiem 1491 istniała osada przedlokacyjna. Miała ona charakter targowy i była już wówczas ośrodkiem administracji terytorialnej i sądownictwa odbywały się w niej sądy książęce.

Po licznych pożarach i zniszczeniach wojennych w wiekach XVII i XVIII Mława odzyskała swoje znaczenie w wieku XIX. Obecnie Mława jest znaczącym miastem w otaczającej ją sieci osadniczej, a jej rola wzrosła zwłaszcza na przestrzeni ostatnich 100 lat. Ostatnie kilkanaście lat to dosyć szybki i wyraźny rozwój miasta, zarówno pod względem realizacji osiedli mieszkaniowych, jak i znaczących inwestycji produkcyjnych. 
Planując dalszy rozwój przestrzenny Mławy zauważono wzrastające znaczenie przystanku kolejowego Mława Miasto, zwłaszcza po jego relokacji w wyniku modernizacji linii kolejowej Warszawa - Gdynia na północ, a więc bliżej „miasta”. Obecnie miasto sporządza projekt planu miejscowego dla rejonu przystanku kolejowego Mława Miasto. Poszukiwane rozwiązania mają z jednej strony zachować tożsamość historyczną i znaczenie zespołu rynku lokacyjnego, z drugiej - wykorzystać centrotwórczy potencjał przystanku kolejowego.

Na podstawie dostępnej literatury oraz map przeanalizowano rozwój przestrzenny Mławy, ze szczególnym uwzględnieniem w tym rozwoju lokalizacji stacji kolejowej Mława oraz przystanku Mława Miasto.

Niniejszy artykuł analizuje dotychczasowe tendencje rozrastania się oraz przemieszczania się strefy centrum w Mławie. Wskazuje także możliwe kierunki dalszych działań planistycznych i przestrzennych, uwzględniając przy tym współczesne tendencje rozwojowe. Artykuł stanowi studium przypadku konkretnej, jednostkowej sytuacji.

\section{Rys historyczny - rozwój przestrzenny i ekonomiczny Mławy}

Mława, obecnie położona w pobliżu północnej granicy województwa mazowieckiego, jest jednym z najstarszych miast Mazowsza. Jej lokacja datowana jest na 13 lipca 1429 r. Przywilej lokacyjny wydali książęta mazowieccy Siemowit V, Kazimierz II i Władysław I na podstawie prawa chełmińskiego, na tzw. surowym korzeniu [Mława 1885; Juszkiewicz 2004; Staszewski 1907] (ryc. 1a i 1b).

W chwili lokacji Mława leżała w północnej części Mazowsza, przy granicy z ówczesnym Państwem Zakonu Krzyżackiego. W średniowieczu przez tereny Zawkrza, na którym leży Mława, przebiegały szlaki handlowe łączące wschodnie Mazowsze z Wielkopolską a także Warszawę z Państwem Krzyżackim. Znaczenie tych ostatnich stało się istotne zwłaszcza na początku XV w.

Pierwszy wczesnośredniowieczny gród na terenie obecnej Mławy (w Kozielsku) powstał zarówno z powodu obronnego charakteru miejsca, jak i w związku z przechodzącymi w pobliżu drogami. Wykopaliska wskazuja, że szlaki te funkcjonowały już w XII - XIII w. Układ dróg na najstarszych dostępnych mapach Mławy pozwala przypuszczać, że istniejący obecnie układ drogowy Mławy w znacznej części pokrywa się z siecią dróg przedlokacyjnych, z korektami wynikającymi z lokacji miasta.

Przygraniczne położenie na szlakach handlowych okazało się bardzo korzystne dla rozwoju miasta. Jego mieszkańcy zajmowali się handlem, głównie bydłem z Rusi. Miasto wielokrotnie otrzymywało przywilejehandlowe, potwierdzane w latach 1543, 1565, 1576, 1602, $1667,1724,1745,1779$. Handlowy charakter miasta potwierdza wytyczony w czasie lokacji stosunkowo duży rynek (120 m x 145 m), który przez stulecia, do okresu dwudziestolecia międzywojennego, był rynkiem targowym. Już w 1477 r. na rynku wybudowano kościół, w 1545 r. król Zygmunt Stary wydał miastu prawo do zbudowania ratusza, który również powstał w przestrzeni rozległego rynku. Główny zespół usługowy skupiał się wokół rynku i w jego przestrzeni (ryc. 2 i 3). 
Ryc. 1a. Mława na mapie Polski i Litwy z lat 1386-1434 - widoczna lokalizacja Mławy przy granicy z Państwem Zakonu Krzyżackiego - żółta kropka

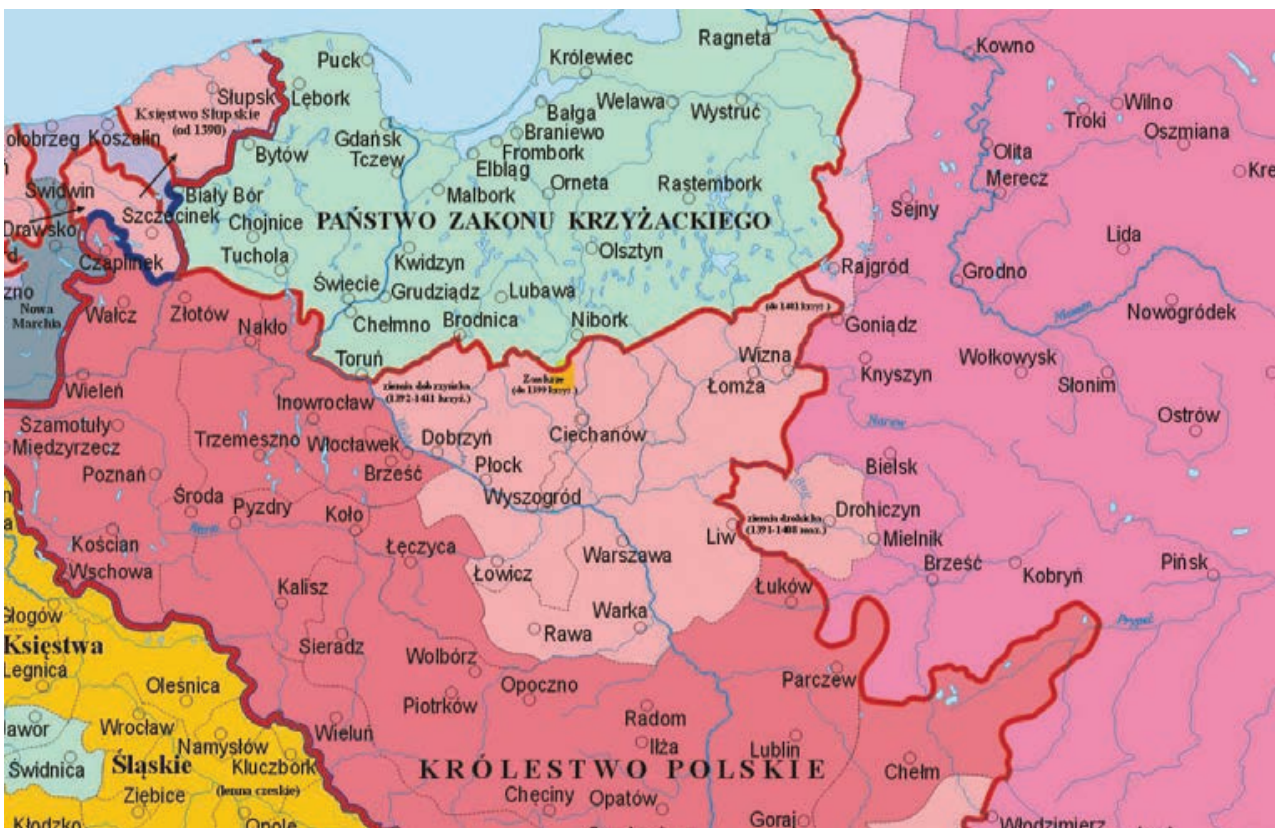

Źródło: Wikipedia.org

Szybki rozwój Mławy miał miejsce w wieku XVI - już od roku 1495 była ona jednym $z$ trzech miast powiatowych ziemi zawkrzeńskiej, włączonej do Mazowsza Płockiego jako dobra królewskie. Siedzibę starosty stanowił nieistniejący już „zamek” w rejonie obecnej Lelewelówki. Miasto liczyło około 2500 mieszkańców, z których $60 \%$ zatrudnionych było $\mathrm{w}$ blisko 250 zakładach rzemieślniczych, skupionych w 12 cechach. Głównymi źródłami dochodów były jarmarki oraz produkcja i eksport do Gdańska piwa, do cechu piwowarów należało 120 mieszkańców. W 1564 r. w Mławie było 429 domów.
Ryc. 1b. Mława na mapie Mazowsza z lat 1248-1351

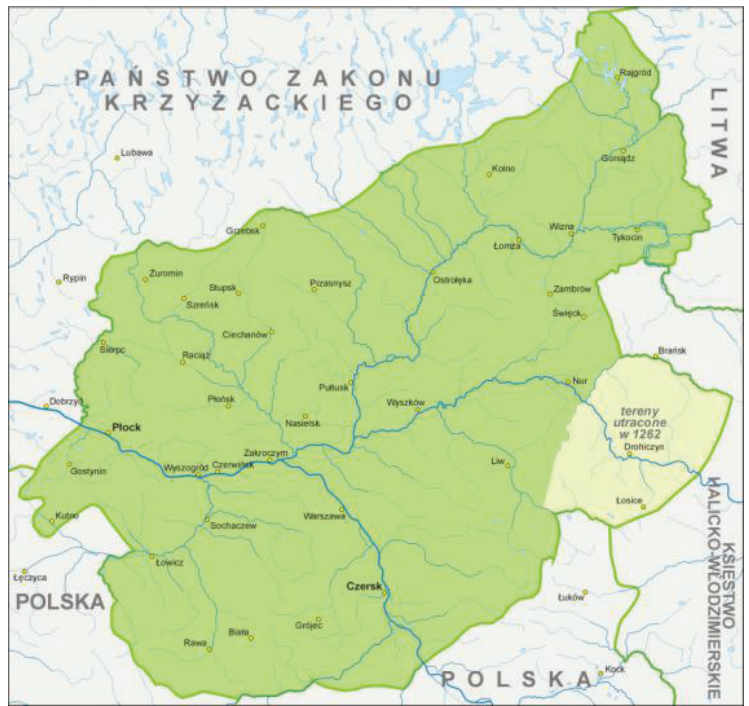

Źródło: Wikipedia.org 
Ryc. 2. Plan pruskiz 1799 r. - analiza wg „Plany przeglądowe miast polskich" A. Kuncewicz, 1929

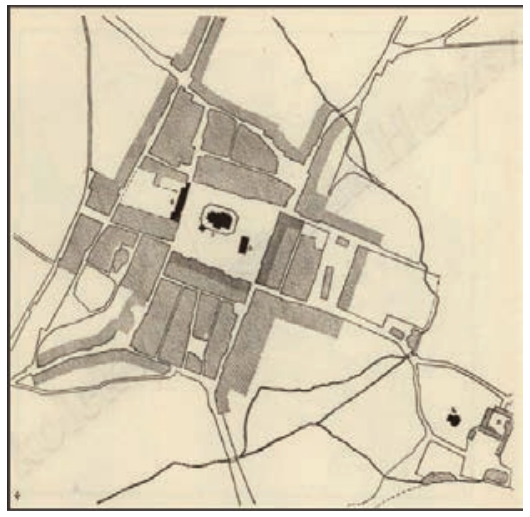

Jednakże zarówno liczne pożary $(1521,1659,1692$, 1776) jak i epidemie dżumy (1572-1573, 1661-1662 i 1708-1712) spowodowały w wiekach XVII i XVIII całkowity spadek znaczenia Mławy, trwający do połowy XVIII w. Upadek miasta najlepiej obrazują fakty: w 1616 r. liczba domów spadła do 320, w 1664 r. do zaledwie 45 (liczba ludności to jedynie 20 rzemieślników).

Rok 1764, to ponowne ustanowienie $\mathrm{w}$ mieście przez sejm koronny starostwa grodowego, miasto było więc siedzibą administracyjną i sądowniczą ziemi zawkrzeńskiej. Liczba domów wynosiła wówczas 85 . Za panowania Stanisława Augusta Poniatowskiego odbudowano ratusz oraz uporządkowano kwestie własności miejskiej. Aby zapobiegać skutkom kolejnych pożarów wybudowano na rynku cztery studnie. Potencjał rozwojowy miasta został ponownie zablokowany przez rozbiory Rzeczpospolitej. Ponownego upadku miasta dopełnił pożar z roku 1783, w którym spłonęły niemalże wszystkie domy [Mława 1885; Juszkiewicz 2004; Staszewski 1907; Ostaszewski 1934; Pazyra 1959; Zygner 2002].

\section{Ryc. 3. Zasięg zabudowy (kolor żółty) wg Planu pruskiego z 1799 r. na tle obecnego zagospodarowania centralnej części Mławy; na czerwono oznaczono zachowane budynki zabytkowe}

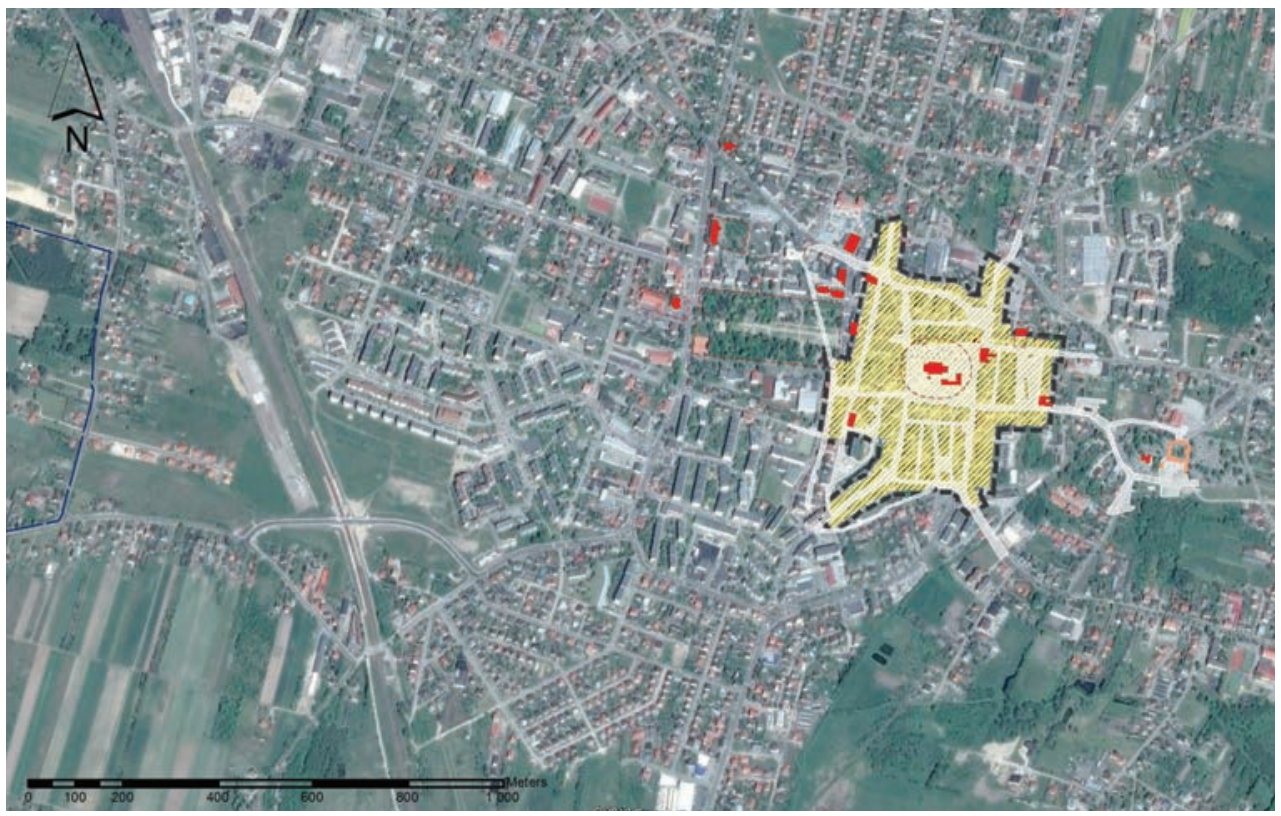

Źródło: Google Maps; analiza porównawcza: Izabela Sobierajska 
Po trzecim rozbiorze Rzeczpospolitej Mława znalazła się w Prusach. W tym czasie miasto dotknęła stagnacja, a przywrócenie równowagi gospodarczej nastąpiło dopiero w czasach Królestwa Polskiego.

W 1840 r. w Mławie przywrócono zarówno siedzibę powiatu jak i sądu okręgowego. Dodatkowo w mieście, ponownie znów przygranicznym, powstała komora celna. Nastąpił tym samym ponowny rozwój handlu oraz rzemiosła. Powstały: szpital (1856), spichlerz (1860), synagoga (1856), zbór ewangelicki (1870) i cerkiew (1879), rozbudowano także kościół parafialny (1882-1886).

Rozwój istotnie przyspieszył wraz z wybudowaniem w sąsiedztwie Mławy linii Kolei Nadwiślańskiej [Staszewski 1907]. Stacja kolejowa w Wólce, położona około 2 km na północny zachód od miasta, była stacją graniczną. Oprócz dworca, w rejonie miasta powstały także komora celna i warsztaty kolejowe. W centrum miasta, w rejonie Nowego Rynku powstała siedziba ochotniczej straży pożarnej (1881). Wokół placu oraz w centralnej części miasta powstawały nowe murowane kamienice, głównie w stylu secesyjnym. W 1905 r., na północ od rynku, wybudowano halę targową. W tym okresie rozwój strefy centralnej odbywał się wokół rynku, z silnym kierunkiem rozwojowym ku północnemu zachodowi. Liczba ludności wzrosła znacząco, do 8 tysięcy, po wybudowaniu kolei. Pod koniec XIX w. w Mławie były trzy place targowe: Stary Rynek z ratuszem i kościołem, Nowy Rynek oraz trzeci, zwany Zielonym. W mieście handlowano głównie zbożem oraz wełną [Mława 1885] (ryc. 4).

\section{Ryc. 4. „Karta geograficzna Drogi żelaznej Nadwiślańskiej z wykazaniem stacyj”, 1876 r. Mława widoczna w północno-zachodnim narożniku}

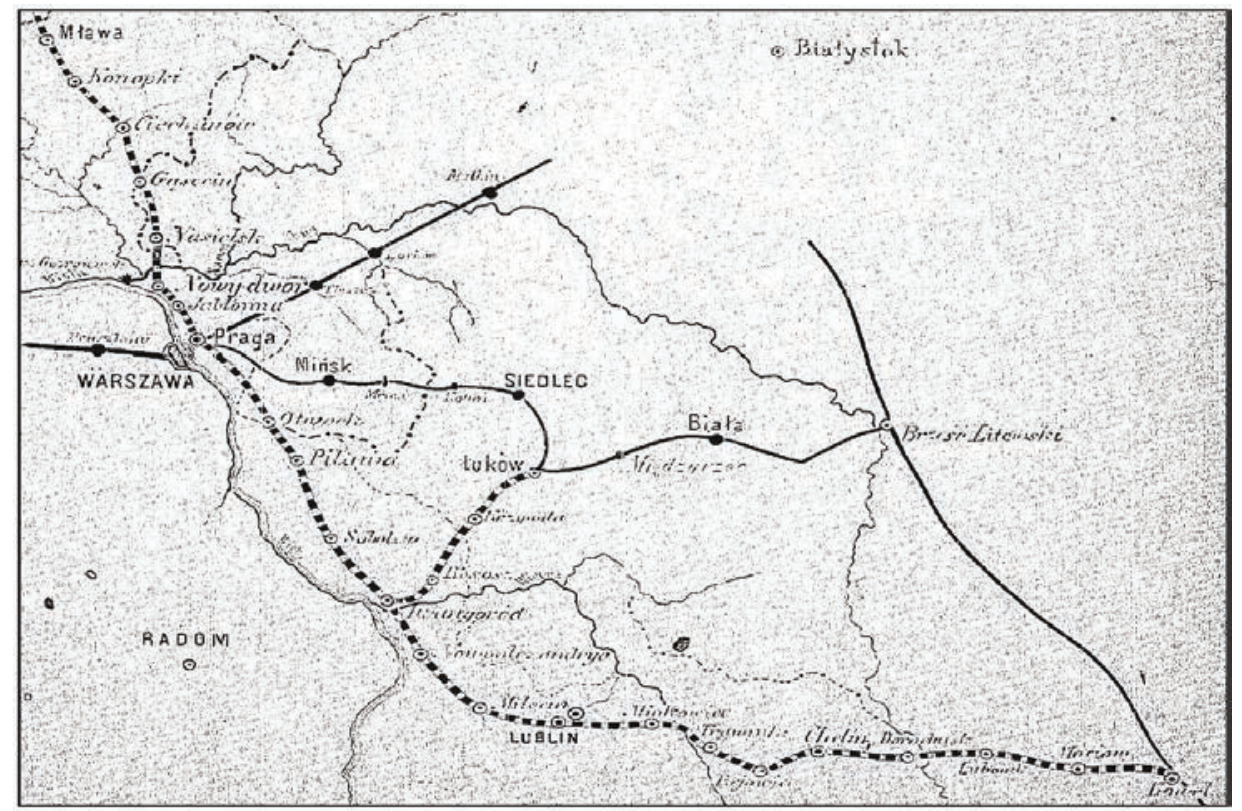

Źródło: Domena publiczna 
Ryc. 5. Plan sytuacyjny Mławy 1923 r. widoczna jeszcze lokalizacja cerkwi św. Jerzego w Parku Miejskim

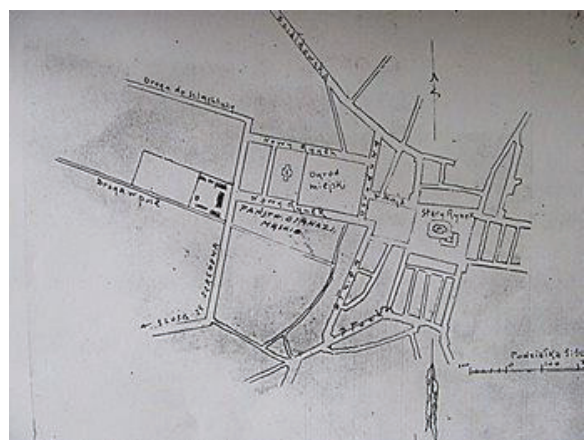

Źródło: Domena publiczna
W początkach XX w. Mława liczyła już 15 tysięcy mieszkańców zamieszkujących około 600 domów. Aż 120 z nich było murowanych [Mława 1885; Juszkiewicz 2004]. Mława stała się najbogatszym miastem północnego Mazowsza. Rozwój przestrzenny następował wyraźnie w kierunku północnym od centrum (osiedle Wójtostwo) oraz wschodnim (na ternach obecnie słabo zainwestowanych), a także północnozachodnim, wzdłuż obecnej ul. Piłsudskiego (w kierunku Wólki). W 1917 r. Wólka formalnie została włączona w granice administracyjne Mławy. W 1921 r. liczba mieszkańców wzrosła do 17 tysięcy [Juszkiewicz 2004; Pazyra 1959; Zygner 2002; new.zawkrze.pl] (ryc. 5 i 6).

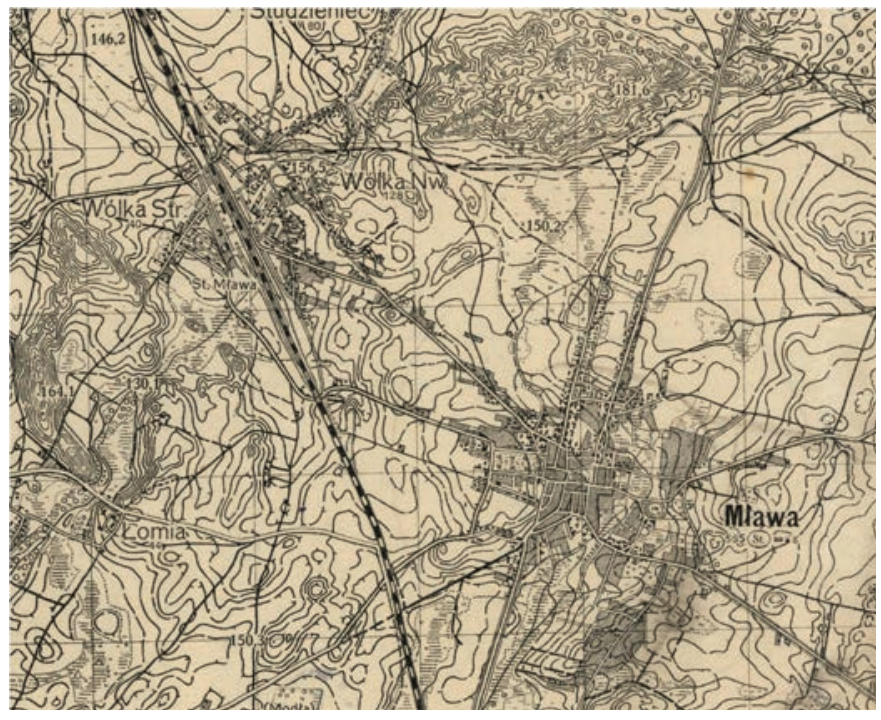

Ryc. 6.

Mapa topograficzna Mławy i okolic 1931 r., widoczne pasmo osadnicze łączące Mławę i Wólkę

W okresie dwudziestolecia międzywojennego miasto ponownie bło siedzibą administracji powiatowej.

II wojna światowa spowodowała zniszczenie 67\% zabudowy w Mławie.

Po wojnie ponownie nastąpił szybki rozwój miasta. Lokalizacja wielu zakładów przemysłowych takich jak: Mławska Fabryka Obuwia, Okręgowa Spółdzielnia Mleczarska, Zakłady Wytwórcze Urządzeń Wodociągowych, Zakłady Urządzeń Dźwigowych, Zakłady Mięsne, Oddział Unitry - wpłynęła na dynamiczny wzrost liczby mieszkańców: w 2001 r. było ich już prawie 31 tysięcy. Miasto rozwijało się głównie w kierunku północnym i północno-wschodnim od centrum, doprowadzając do przestrzennego powiązania dawniej 
Ryc. 7. Zasięg zabudowy (kolor zółty) wg map WIG z lat 30. XX w. na tle obecnego zagospodarowania centralnej części Mławy; czarna obwódka wskazuje zasięg zabudowy z 1799 roku i w zasadzie pokrywa się z obszarem zabudowy zwartej, na pozostałych obszarach zabudowa była rozproszona; na czerwono oznaczono zachowane budynki zabytkowe

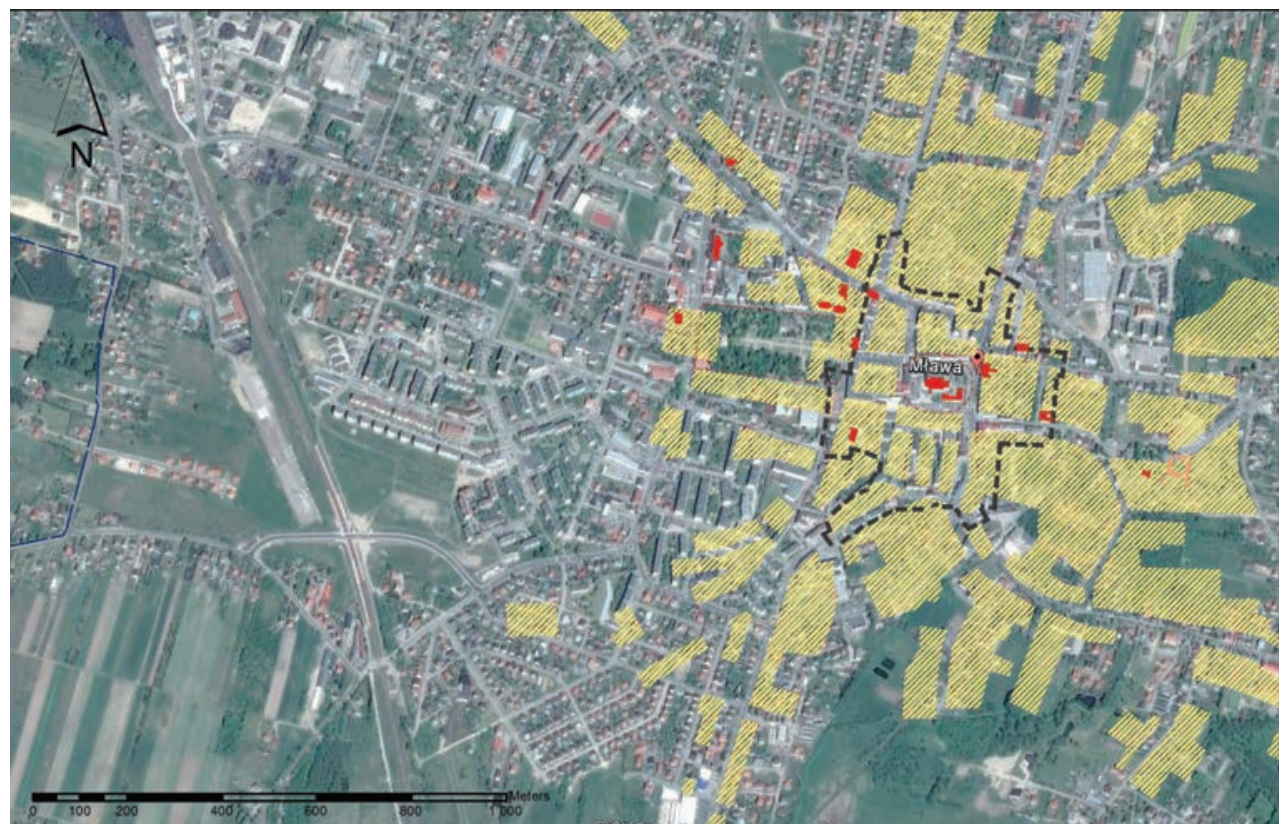

Źródło: Google Maps; analiza porównawcza: Izabela Sobierajska

Ryc. 8.

Widok od północnego wschodu na zniszczenia wojenne w centrum Mławy - widoczne ruiny dawnych kamienic w północnej pierzei Starego Rynku

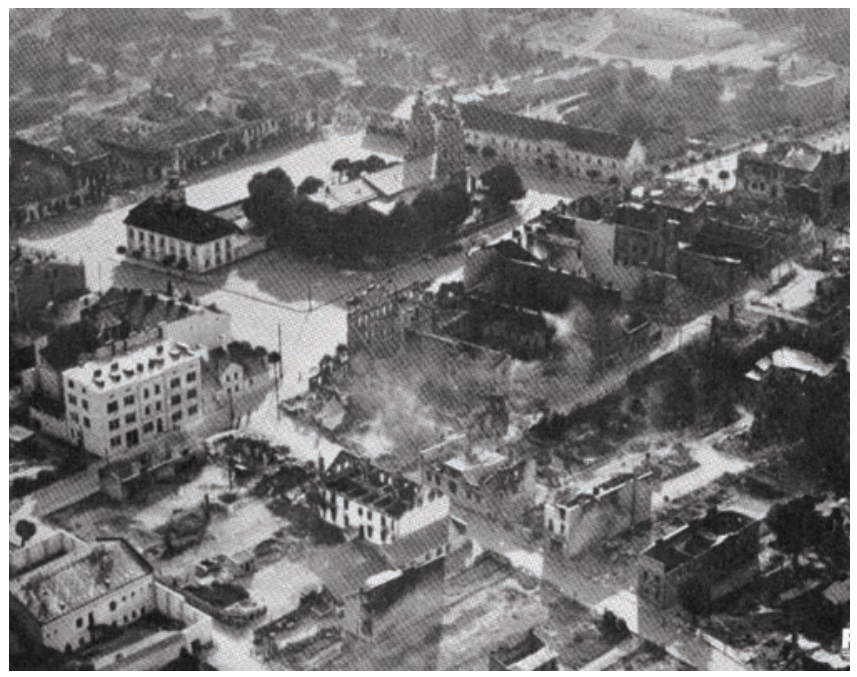


oddzielnych osad: Mławy i Wólki. Sprzyjała temu lokalizacja zakładów przemysłowych przy linii kolejowej, pomiędzy Mławą a Wólką. Miasto rozbudowało się od północy niemalże do Lasu Mławskiego, powstały w tej części miasta liczne osiedla jednorodzinnej zabudowy mieszkaniowej. W rejonie centralnym, z przewagą w kierunku południowym od centrum dominowała nowa zabudowa wielorodzinna spółdzielni Zawkrze. Wzniesiono ją głównie w latach 60., 70. i 80. XX wieku. Realizacji zespołów mieszkaniowych w tym rejonie sprzyjało uruchomienie nowego przystanku kolejowego Mława Miasto, zlokalizowanego na południowy zachód od strefy centralnej, historycznej miasta. Jednakże pierwszych 7 bloków, zrealizowano w wyburzonych pierzejach rynku oraz na południe od niego; w latach 19581966 oddano do użytku 150 mieszkań. Dopiero kolejne realizacje powstawały w większej odległości od zespołu historycznego: w rejonie ul. Sienkiewicza (na południe od centrum), a także ul. Tuwima i Szpitalnej ( na północny zachód od centrum - os. Młodych). W okresie od 1967 aż do 1984 r. powstało łącznie ponad 80 bloków mieszkalnych w strefie śródmiejskiej [new.zawkrze.pl], (ryc. 9)

Lata 80. to także początek budowy osiedla Książąt Mazowieckich, położonego najbliżej stacji Mława Miasto, pomiędzy stacją a centrum miasta. Na przełomie XX i XXI w. powstały kolejne osiedla wielorodzinne w tym rejonie, coraz bliżej linii kolejowej i stacji. Obecnie zurbanizowano większość terenów położonych wzdłuż linii kolejowej po jej północnowschodniej stronie. W części północno-zachodniej zabudowane są również tereny na zachód od stacji. W rejonie Wólki i istniejącego tu dworca kolejowego rozwinęła się zabudowa o mieszanych funkcjach: zarówno mieszkaniowa jednorodzinna, usługowa, jak i magazynowo-składowa.

\section{Ryc. 9. Widok od północy na centrum Mławy w latach 70., widoczne bloki mieszkalne spółdzielni Zawkrze zrealizowane wokół Starego Rynku}

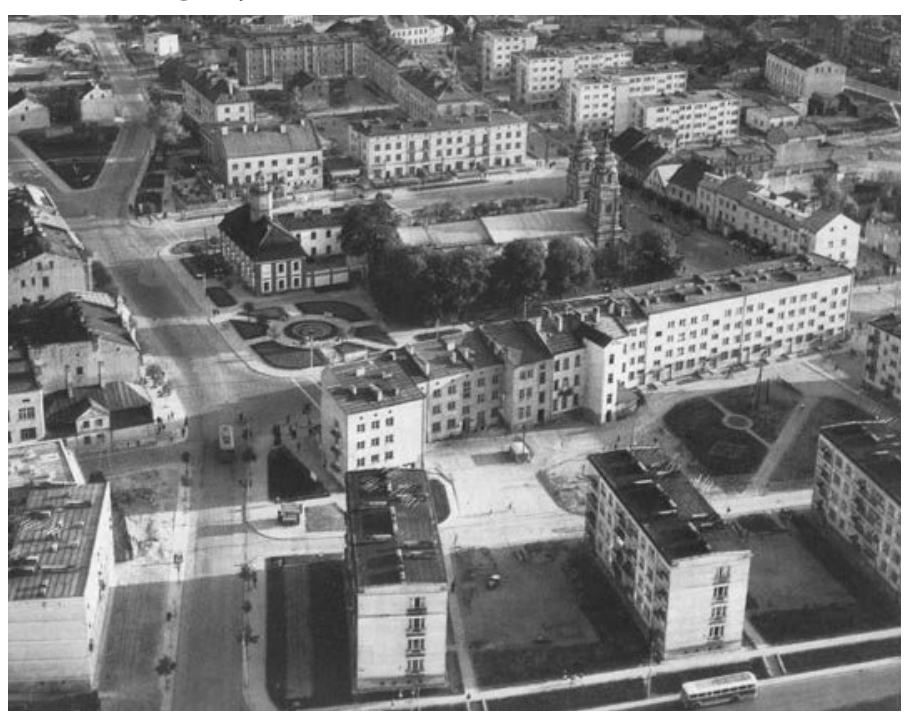




\section{Obiekty i obszary centrotwórcze w Mławie}

Jak już wspomniano, pierwotnie centrum miasta stanowił sam rynek lokacyjny wraz z kościołem i ratuszem oraz z częścią otaczającej go zabudowy. Taki stan rzeczy utrzymywał się w zasadzie do końca XIX w. kiedy to szybki rozwój miasta związany był z powstaniem Kolei Nadwiślańskiej.

\section{Ryc. 10. i 11. Widok ratusza i rynku w Mławie w okresie dwudziestolecia międzywojennego - po lewej stronie -9 parterowych sklepów}

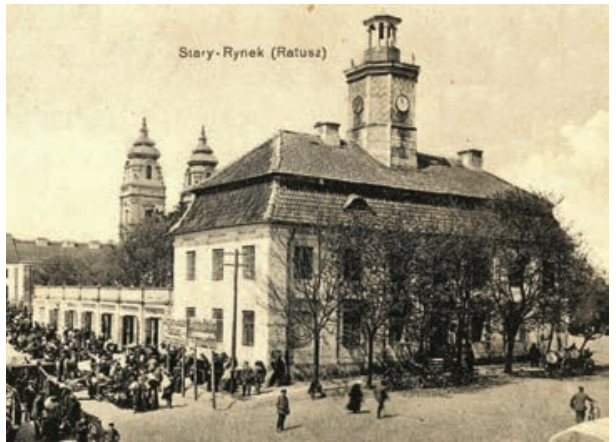

Żródło: https://janiss67.pl.tl/RATUSZ--MIEJSKI.htm

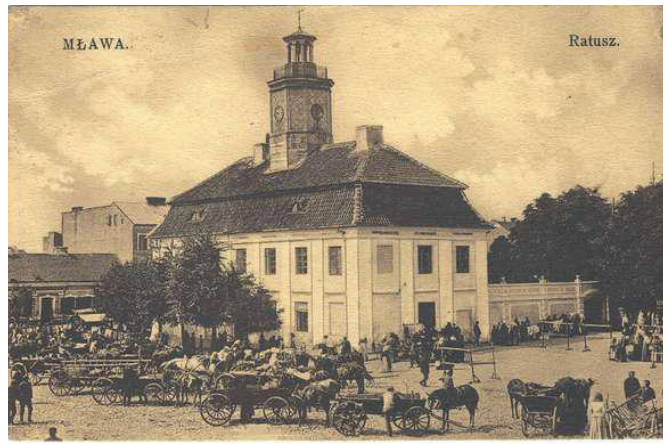

źródło: http://docplayer.pl/16366821-Mlawa-w-starejfotografii.html

Na przełomie XIX i XX w. w mieście funkcjonował już zespół czterech głównych, publicznych rynków: Starego, Nowego, Zielonego i Rybnego (Przyrynku), obok których istniał rozległy Park Miejski. Stanowiły one, wraz z otaczającą je i częściowo wprowadzoną w ich przestrzeń zabudową, funkcjonalne centrum Mławy (ryc. 10 i 11).

Stary Rynek pełnił funkcje głównego placu targowego oraz reprezentacyjnego w mieście. Na rynku, w części północno-zachodniej funkcjonował kościół parafialny. W części wschodniej stał ratusz, obok którego w ramach przebudowy z 1876 r. dobudowano od strony południowej 9 parterowych sklepów, które miasto dzierżawiło kupcom.

Położony na wschód od głównego Rynek Zielony, czyli obecny Plac 1 Maja, to pierwotnie nieutwardzony plac, na którym handlowano bydłem i trzodą. W części północnej placu od końca XIX w. działała szkoła powiatowa. Jej powstanie wymusiło relokację funkcji targowych z placu i przekształcenie go w ogrodzony, zielony ogród miejski (ryc. 12 i 13).

Handel zwierzętami jeszcze w połowie XIX w. przeniesiono do Nowego Rynku, założonego na zachód w stosunku do Starego. W jego północnej pierzei powstały gmachy użyteczności publicznej: Kasa Powiatowa oraz Urząd Finansowy. Na północ od tego rynku, na końcu ul. Żeromskiego, wybudowano halę targową w której mieściło się 36 jatek mięsnych oraz sklepy rybne.

Nowy Rynek przetrwałdoI wojny światowej, kiedy to zostałwłączony doParku Miejskiego. Ta przestrzeń z kolei powstała z rozbudowy ogrodu otaczającego cerkiew prawosławną oraz części ogrodu misjonarskiego przy dawnym klasztorze misjonarzy, istniejących na zachód 
Ryc. 12. i 13. Widok na Zielony Rynek (obecnie 1 Maja) - początek XX w. - w perspektywie gmach szkoły powiatowej; widoczne nasadzenia drzew na dawnym placu

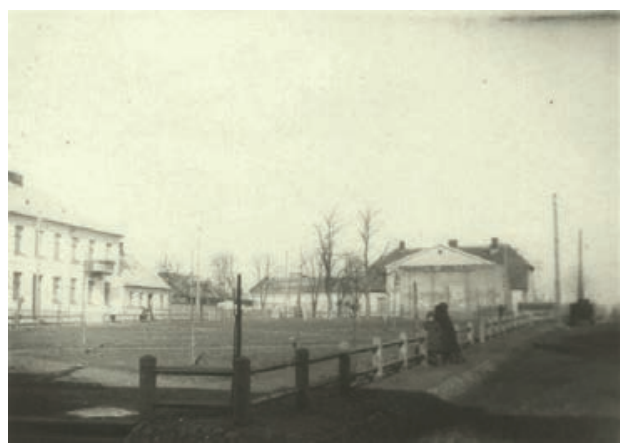

Żródło: https://janiss67.pl.tl/RATUSZ--MIEJSKI.htm

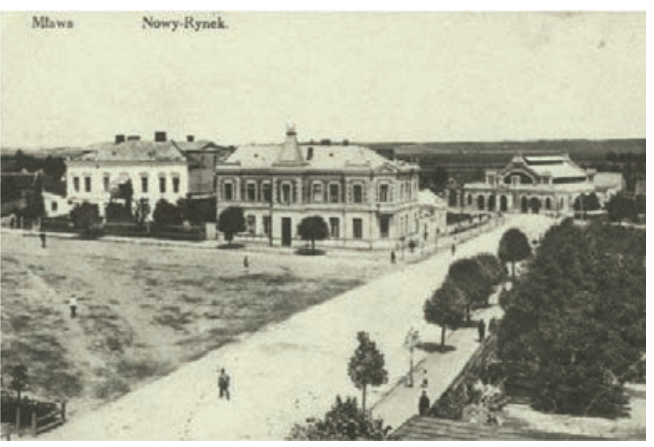

Żródło: http://docplayer.pl/16366821-Mlawa-w-starej-fotografii.html

od Starego Rynku, a obecnie niezachowanych. Po ostatecznym ukształtowaniu Parku był on otoczony głównie budynkami usługowymi, oprócz wcześniejszych klasztoru czy cerkwi, Kasy Powiatowej i Urzędu Finansowego, także teatrem miejskim (obecnie biblioteka), Szkołą Handlowa, Szkołą Żeńska, hotelem, restauracją kancelarią adwokacką oraz domami rzemieślników (ryc. 14).

\section{Ryc. 14. Widok na park i miasto od strony Cerkwii (1900)}

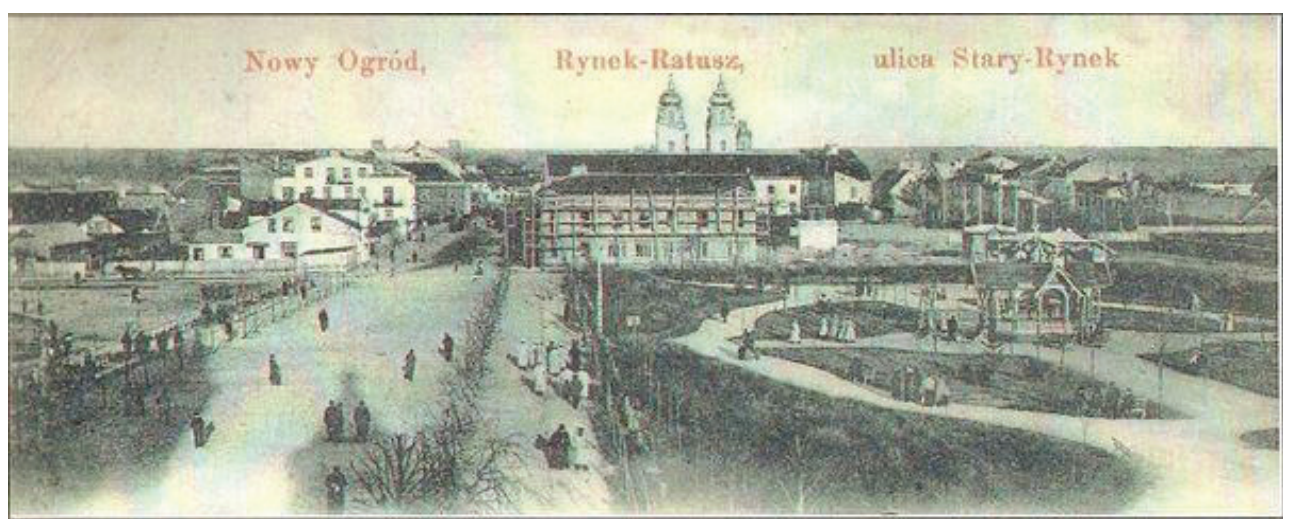

Żródło: http://kuriermlawski.pl

Z kolei Przyrynek, położony u wlotu ul. Warszawskiej do Starego Rynku, od strony południowej, wyspecjalizował się w handlu rybami. Pod koniec XIX w. w przestrzeni tego targowiska powstały kramy. Podobnie jak te przy ratuszu były one murowane, na podmurówce (ryc. 15 i 16).

Odbudowa powojenna istotnie przekształciła układ funkcjonalno-przestrzenny miasta. Szybki rozwój nowych osiedli mieszkaniowych w latach 60., 70. i 80. pociągnął za sobą rozwój usług. Nowe obiekty administracji, policji i sądów oraz przebudowane liceum 
Ryc. 15. Widok na Park Spacerowy w pespektywie alei parkowej widoczna cerkiew prawosławna

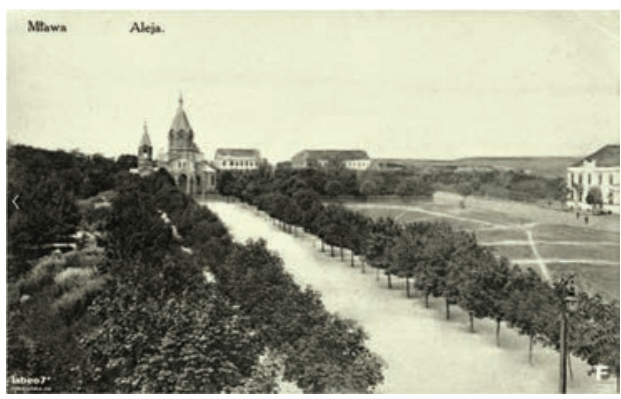

Żródło: https://janiss67.pl.tl/RATUSZ--MIEJSKI.htm

\section{Ryc. 16. Widok na Przyrynek - początek XX w. - po lewej widoczne kramy}

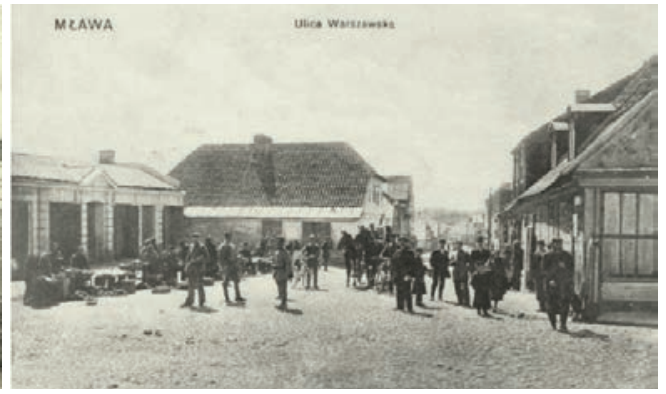

Żródło: http://docplayer.pl/16366821-Mlawa-w-starej-fotografii.html

i bibliotekę (dawny teatr) ulokowano wokół Parku Miejskiego, aż po ul. Sienkiewicza. Funkcje handlowe intensywnie rozwijały się na północny zachód od Starego Rynku. Na tzw. Placu 3 Maja powstał na początku lat 60. duży jak na skalę miasta, trzykondygnacyjny, modernistyczny dom towarowy. Z czasem jego otoczenie wypełniły pawilony handlowe, zarówno dwukondygnacyjne jak i parterowe, tworząc ponadlokalny zespół handlowo-gastronomiczny (ryc. 17 i 18). Także ciąg ulic Sienkiewicza Lelewela został częściowo obudowany usługami ogólnomiejskimi. Wzniesiono tu hotel i drobniejsze pawilony handlowe.

Na przełomie XX i XXI w. nowe obiekty usługowe intensywnie wypełniły zachodnią część śródmieścia. Wyraźny ciąg handlowo-usługowy ukształtował się obecnie wzdłuż ulic Sienkiewicza Lelewela. Funkcjonuje tutaj obecnie kilka

Ryc. 17. Dom towarowy zrealizowany na Placu 3 Maja - powstałym na północny zachód od Starego Rynku, proj. Stanisław Kolendo (1962)

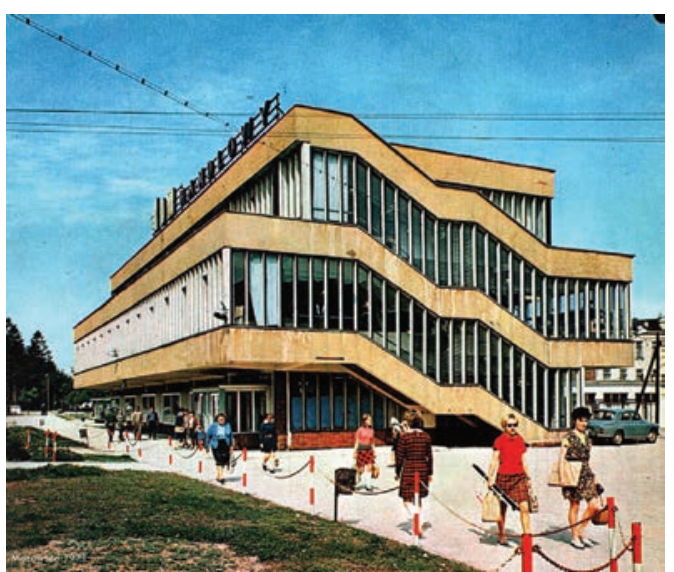

Źródło: Domena publiczna

średniej wielkości sklepów typu Lidl czy Tesco, bursa szkolna, komenda policji, banki, centrum nauki i biznesu oraz drobne sklepiki. W rejonie osiedla Książąt Mazowieckich, pomiędzy centrum historycznym a stacją Mława Miasto, również powstały zarówno dwukondygnacyjne pawilony handlowe jak i duże sklepy osiedlowe. Nadal następowała i następuje intensyfikacja usług w części centrum historycznego, poprzez rozbudowę istniejących tu już wcześniej pawilonów (ryc. 19).

Najnowsze realizacje wzmacniają wyraźnie zarysowujący się w mieście układ centrum w formie pasmowej, na osi wschód-zachód. Na północny wschód od Starego Rynku od 5 lat 
Ryc. 18. Dom handlowy na Placu 3 Maja otoczony pawilonami - stan w 2016 r.

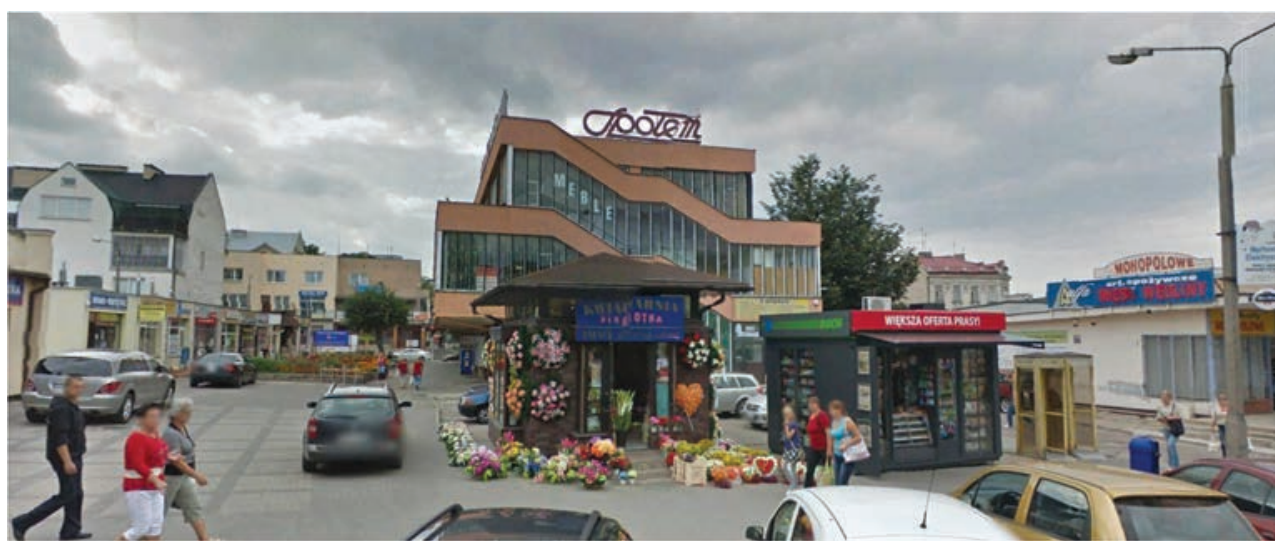

Źródło: Google Maps

Ryc. 19. Pawilony handlowe przy skrzyżowaniu ul. Sienkiewicza i Ordona, w rejonie osiedla Książąt Mazowieckich - stan w 2016 r.

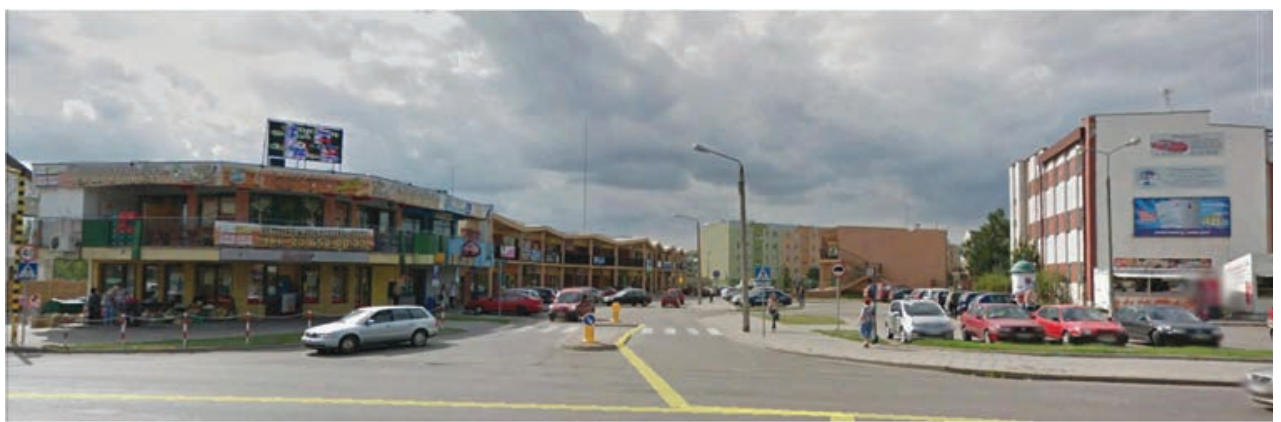

Źródło: Google Maps

Ryc. 20. Centrum handlowe na północny wschód od Starego Rynku - stan w 2016 r.

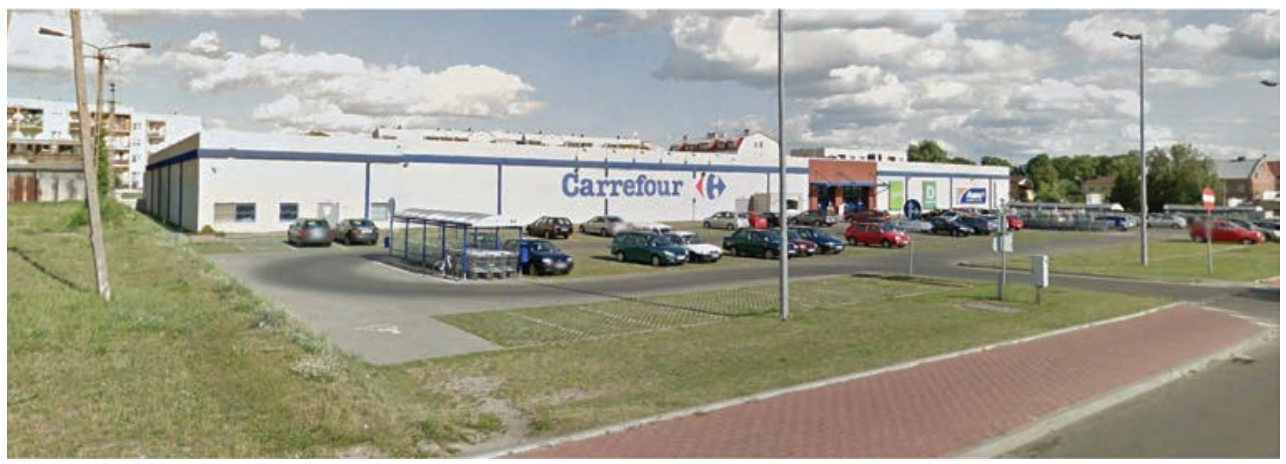

Źródło: Google Maps 
funkcjonuje wielkopowierzchniowy, parterowy obiekt handlowy. W planach przewidziane jest uzupełnienie tej inwestycji budynkiem biurowym oraz hotelem, powstać tutaj mają także drobne usługi sportu i rekreacji. Docelowo zespół ma przyjąć formę miejskiego centrum handlowo-rozrywkowego z częścią biurowo-hotelową (ryc. 20).

Rozbudowa tego obiektu, obecnie parterowego i o niewyszukanej oprawie architektonicznej, wydaje się koniecznością. Parterowe hale w centralnej części miasta nie dodają mu urody ani prestiżu. Przebudowa i częściowa nadbudowa powinny zmierzać do uzyskania reprezentacyjnego, miejskiego charakteru przez ten fragment przestrzeni śródmieścia Mławy.

Z kolei w sąsiedztwie stacji Mława Miasto, na zachodnim krańcu rozrastającego się zespołu centrum, powstać ma zintegrowany zespół dworcowy. W pobliże stacji kolejowej ma zostać relokowany dworzec autobusowy, dotychczas funkcjonujący na północny wschód od Starego Rynku. Obecna stacja kolejowa ma zostać uzupełniona o nowe pomieszczenia dworcowe, ponieważ istniejący budynek dworca położony jest na południe od nowych peronów. W trakcie modernizacji linii kolejowej stacja została przesunięta o około $0,5 \mathrm{~km}$ na północ w stosunku do jej poprzedniego położenia, a budynek dworca pozostał na dawnym miejscu. Zgodnie ze zmianą Studium UiKZP Mławy z grudnia 2015 r. władze miasta zakładają w rejonie stacji realizację obiektu handlowego o powierzchni sprzedaży powyżej $2000 \mathrm{~m}^{2}$. Dla tego obszaru procedowany jest projekt planu miejscowego, którego intencją jest powstanie obiektu handlowego z wbudowanymi pomieszczeniami dworców kolejowego i autobusowego.

Planowana inwestycja będzie miała istotne znaczenie dla wzmocnienia zachodniego rejonu centrum w mieście. Wraz z drugim obiektem wielkopowierzchniowym, znajdującym się na wschodnim krańcu centrum, najprawdopodobniej na długie lata utrwali jego równoleżnikowy układ.

W tej sytuacji kluczowym zadaniem, stojącym zarówno przed samorządem jak i przed inwestorami, jest wzmocnienie ciągu pieszego prowadzącego obecnie bardzo wydłużoną trasą pomiędzy stacją a centrum historycznym. Zwłaszcza inwestycja w rejonie stacji wymaga umiejętnego przeprowadzania ogólnodostępnego przejścia w kierunku osiedla Książąt Mazowieckich. Dalej powinno ono prowadzić do ul. Sienkiewicza i wzdłuż niej poprzez Park Miejski do Starego Rynku i do kolejnego centrum handlowego położonego na północny wschód od niego. W rejonie Parku ciąg ten powinien rozchodzić się na dwie części - przebiegające na północ i na południe od niego. W ten sposób zachowane zostanie znaczenie Starego Rynku jako głównej, reprezentacyjnej i handlowej przestrzeni miejskiej.

Same historyczne place miejskie: Stary Rynek i Plac 1 Maja oraz najnowszy Plac 3 Maja wymagają pilnej modernizacji i rewitalizacji. To zagadnienie wymaga oddzielnego opracowania.

Problemem dotyczącym wizerunku miasta jest niska jakość nowej architektury usługowej, zwłaszcza obiektów handlowych. Ich porównanie z obiektami zabytkowymi wyraźnie wskazuje na regres w sztuce architektury. Różnej wielkości parterowe pawilony są najmniej 
trafną formą jaką zwłaszcza w centrum powinny przyjmować usługi o znaczeniu ogólnomiejskim i ponadlokalnym. Kolejne wyzwanie dla władz samorządowych i inwestorów to porządkowanie przestrzeni oraz podnoszenie standardu zabudowy.

\section{Znaczenie miasto - i centrotwórcze stacji Mława Miasto - problemy funkcjonalne po przebudowie stacji}

Oceniając potencjał śródmieścia Mławy i jego bezpośredniego sąsiedztwa należy przede wszystkim wspomnieć o terenach położonych w pobliżu stacji kolejowej Mława Miasto oraz o samym znaczeniu tej stacji dla rozwoju śródmieścia i centrum miasta (ryc. 21, 22, 23).

Jak już wspomniano, Kolej Nadwiślańska została pierwotnie (1877) zrealizowana w odległości około 750-800 m w linii prostej od Mławy. Przy czym stację Mława, zwaną potocznie stacją Mława-Wólka, odsunięto od miasta o prawie $2 \mathrm{~km}$. Była ona wówczas stacją graniczną pomiędzy zaborami rosyjskim i pruskim, gdzie łączyły się rosyjska Kolej Nadwiślańska i pruska kolej malborsko-mławska. Obie linie kolejowe miały różny rozstaw torów i dlatego w Mławie zamontowane były urządzenia przestawcze. Dodatkowo w czasie I wojny światowej w rejonie Wólki powstała stacja kolejki wąskotorowej, prowadzącej do Przasnysza, omijającej miasto od północy i wschodu. Stąd też historycznie dworzec kolejowy w Wólce miał wyższą rangę od współczesnej stacji Mława Miasto. Ale to właśnie z tej drugiej stacji można dojść pieszo do centrum miasta i przede wszystkim do zespołów zabudowy mieszkaniowej wielorodzinnej położonych na południe i południowy zachód od niego.

W latach 2009-2014 linia kolejowa nr 9 (E65) relacji Warszawa - Iława - Malbork Gdańsk została zmodernizowana. W ramach tej inwestycji w granicach Mławy istotnie przebudowano zarówno dworzec w Wólce, jak i stację Mława Miasto. Pomimo wniosków samorządu, nadal, jako ważniejszy dworzec funkcjonuje ten w Wólce. Ze względu na swoje położenie na północny zachód od strefy centralnej miasta, w pobliżu rozrastającej

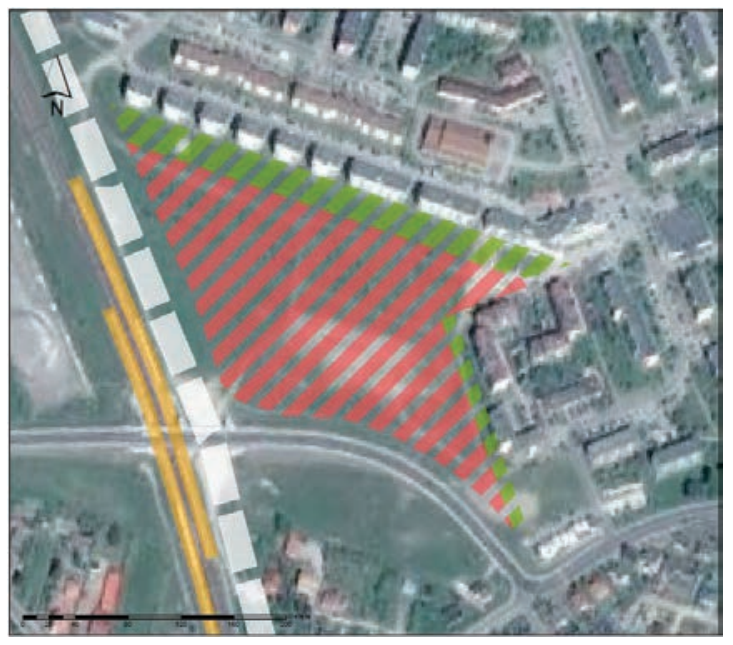

Ryc. 21.

Rejon zmodernizowanej stacji Mława Miasto - stan w 2016 r. - w części zachodniej widoczna linia kolejowa wraz z peronami stacji (kolor jasnopomarańczowy) i wiaduktem drogowym; na różowo oznaczono rejon lokalizacji zespołu dworcowo-handlowego; zielony szraf to strefy buforowe, wskazane do zachowania jako zieleń urządzona, pomiędzy istniejącą i planowaną zabudową

Źródło: Google Maps;

analiza porównawcza: Izabela Sobierajska 
się dzielnicy produkcyjnej, powinien on raczej służyć do obsługi pociągów regionalnych, dowożących pracowników do tej dzielnicy. To stację Mława Miasto należałoby rozbudować jako główny dworzec kolejowy w mieście. Jednak nie stało się tak, pomimo iż dokumenty

Ryc. 22. Problemy dostępności stacji Mława Miasto:

jasnopomarańczowe linie - perony;

zielone poligony - schody na wiadukt;

zielone kropki - najkrótsze drogi dojścia pieszego ze stacji w kierunku centrum;

żółte kropki - wydłużone drogi dojścia dla niepełnosprawnych w przypadku awarii wind oraz dojścia od miejsc postojowych obsługujących perony;

ciemna niebieska linia przerywana - projektowana droga zbiorcza, częściowo w trakcie realizacji;

szraf czerwony - rejon lokalizacji dworca zespolonego z centrum handlowym;

pomarańczowe podwójne kropki - optymalna droga dojścia pieszego, obecnie prowadząca przez łąkę;

jasnopomarańczowy szraf - przestrzeń publiczna do zaaranżowania jako reprezentacyjna, wejściowa do strefy śródmiejskiej

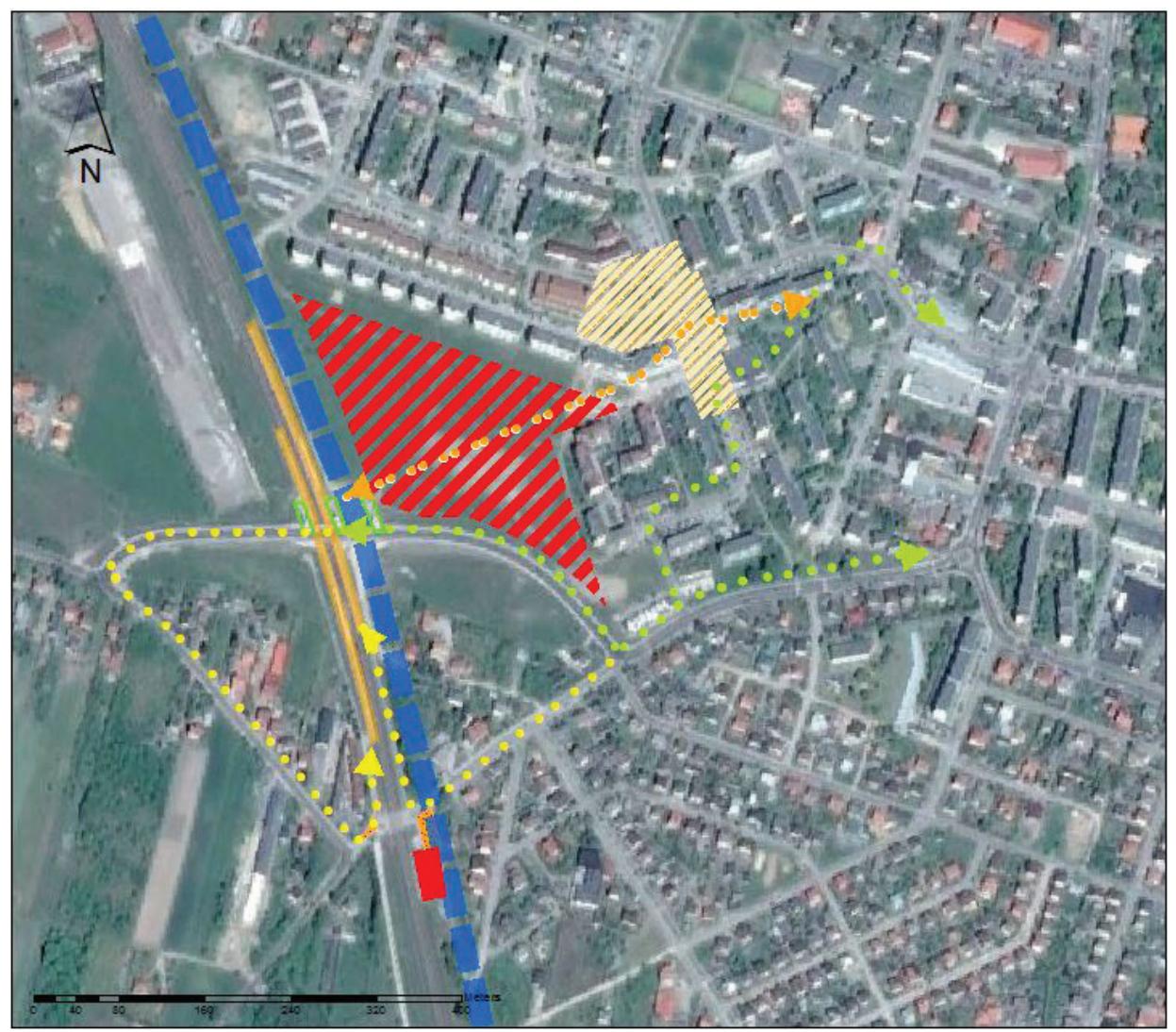

Źródło: Google Maps; analiza porównawcza: Izabela Sobierajska 
Ryc. 23. Obiekty i obszary centrotwórcze w Mławie, z podziałem na etapy powstawania: 1 - najstarsze zespoły historyczne: 1a-układ lokacyjny, 1b-nieistniejący księży folwark, 1c - “Lelewelówka”, rejon nieistniejącego Zamku; 2 - place z przełomu XIX i XX w.: 2a - nieistniejący Nowy Rynek, 2b - Rynek Zielony (obecnie 1 Maja), 2c - nieistniejący Rynek Rybny (Przyrynek); 3 - Park Miejski; 4 - główny obszar z funkcjami centrotwórczymi w mieście; $5 a$ - istniejące nowe centrum handlowe, 5b - projektowany zespół dworców kolejowego i autobusowego $z$ centrum handlowym

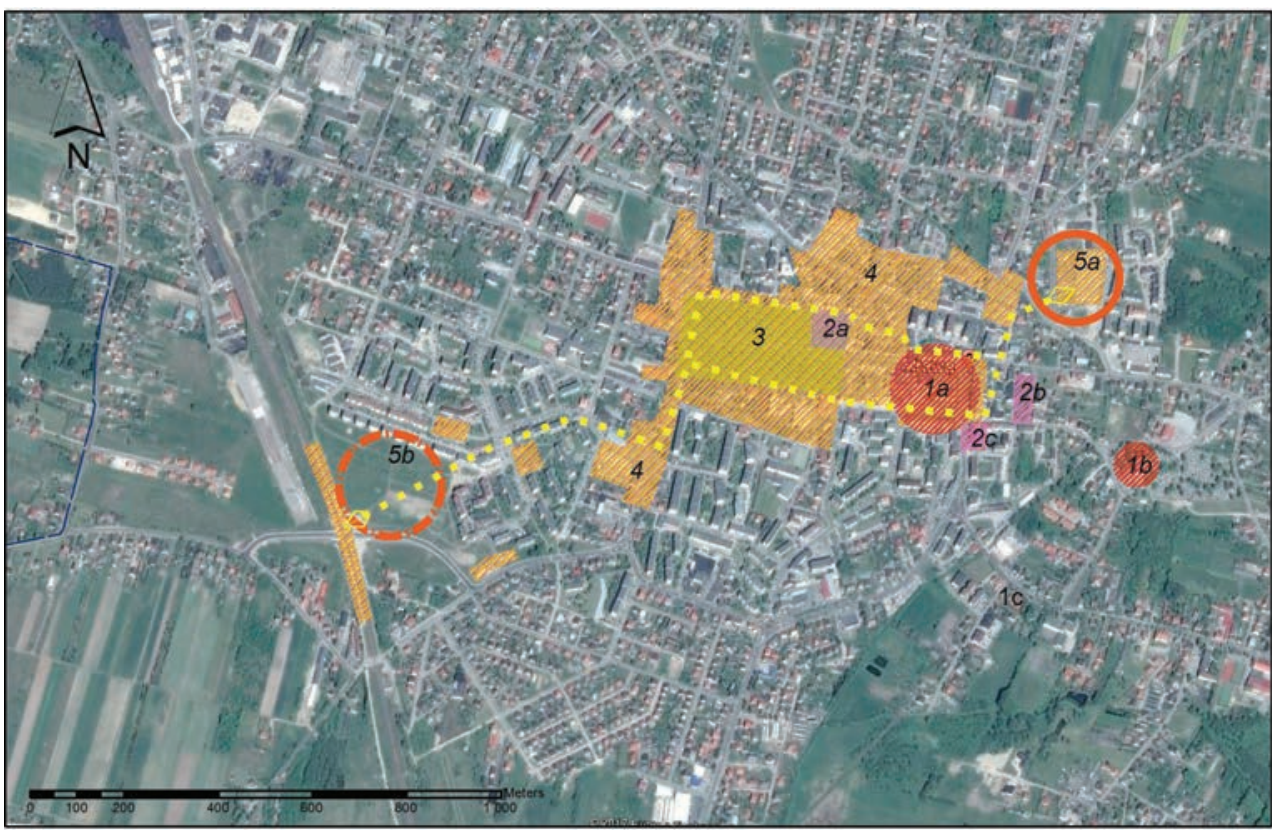

Źródło: Google Maps; analiza porównawcza: Izabela Sobierajska

planistyczne miasta zakładaja, że właśnie w rejonie południowej stacji zrealizowany zostanie zintegrowany dworzec kolejowo-autobusowy, powiązany z centrum handlowym. W celu jego obsługi miasto realizuje właśnie ciąg drogi zbiorczej biegnącej wzdłuż linii kolejowej po jej północno-wschodniej stronie. Doga ta umożliwi, wraz z drogami już istniejącymi, dogodny dojazd do stacji w skali całego miasta i sąsiednich miejscowości.

Potencjał centrotwórczy stacji Mława Miasto jest bardzo duży, miasto w swojej części śródmiejskiej konsekwentnie się do niej zbliża od momentu jej uruchomienia. Nowo zrealizowane przesunięcie peronów stacji na północ, bliżej głównych ciągów pieszych prowadzących do centrum, powinno być ocenione pozytywnie. Niestety, w trakcie przebudowy stacji popełniono kilka błędów skutkujących jej ograniczoną dostępnością. Nowe perony dostępne są jedynie albo od strony chodnika wiaduktu drogowego wybudowanego nad stacja, albo od strony krańców południowych, położonych dalej od śródmieścia. Zejścia z wiaduktu na perony zapewniają schody i windy, ale te ostatnie są awaryjne. Największy problem funkcjonalny wynika z faktu, że jezdnie od chodników na całej długości wiaduktu oddzielone 
Ryc. 24. Wiadukt drogowy linii kolejowej E65 Warszawa - Gdynia w ciągu ul. Klasyków i ul. Bohaterów w Warszawie - projekt zrealizowany; Krzysztof Nadany

Zaznaczone zatoki przystanków autobusowych na wiadukcie, umożliwiające dogodną przesiadkę kolej/autobus

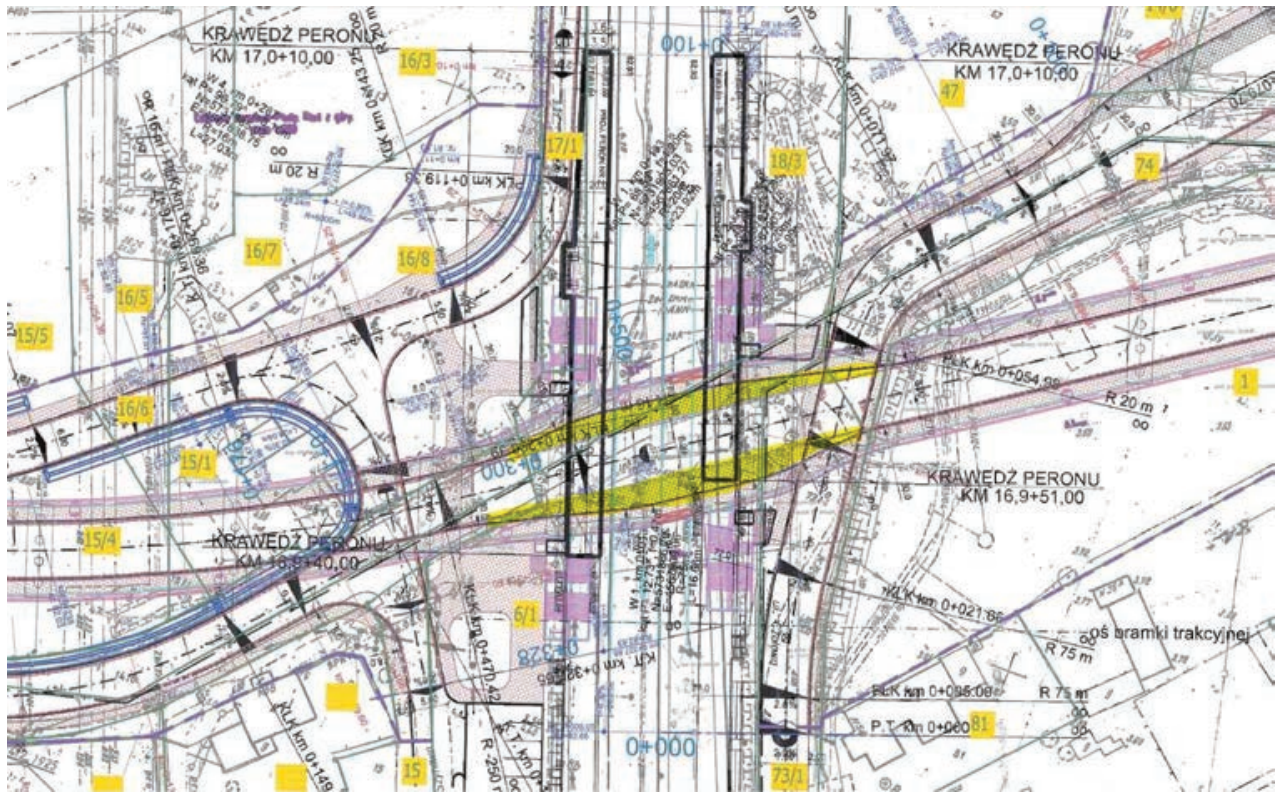

Źródło: opracowanie własne

Ryc. 25. Widok na wiadukt drogowy linii kolejowej E65 Warszawa - Gdynia w ciągu ul. Klasyków i ul. Bohaterów w Warszawie - widoczne schody i windy prowadzące z wiaduktu na perony, jako najkrótsza możliwa droga dojścia ze stacji do przystanków autobusów miejskich

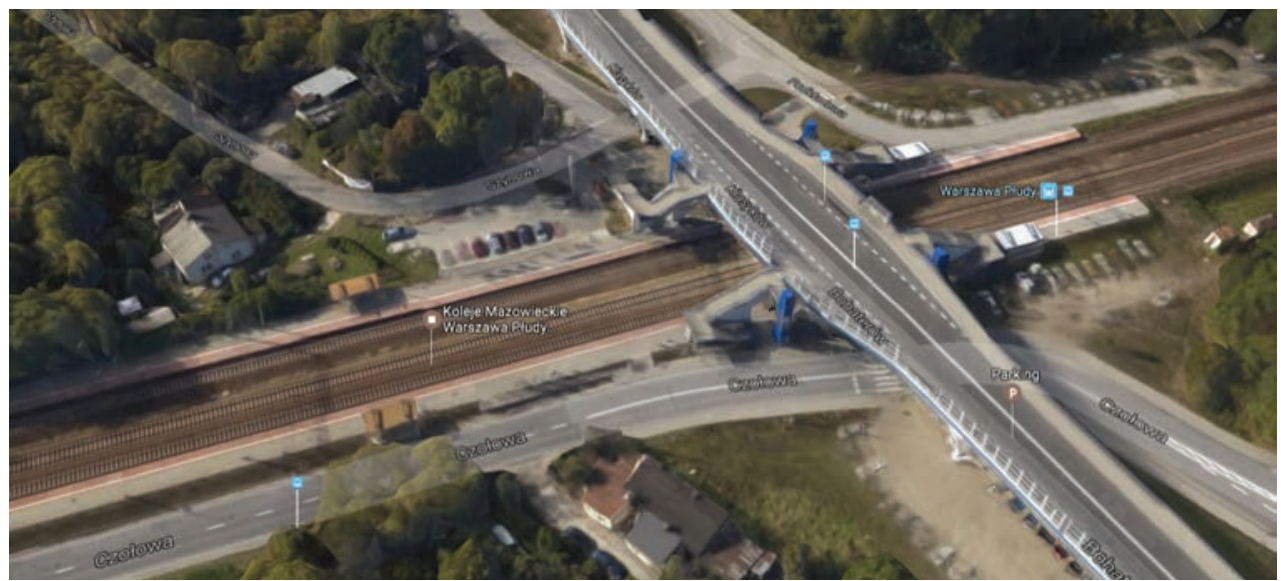

Źródło: Google Maps 
są barierkami. W tej sytuacji podjechanie na wiadukt z walizkami i zejście po schodach bezpośrednio na perony nie jest możliwe. Do peronów można, co prawda, podjechać od strony południowej, w rejonie dawnego przejazdu przez tory i podejść w poziomie terenu, ale podjazdy te są prowizoryczną pozostałością po dawnym przejeździe przez tory. Dojście od tych podjazdów do peronów nie jest krótkie: w przypadku peronu wschodniego do jego północnego krańca ta droga ma ponad $450 \mathrm{~m}$. Jednocześnie to właśnie w rejonie dawnego przejazdu nadal funkcjonuje budynek dworcowy z poczekalnią i kasami. Zakup biletu i przejście na peron zachodni wymaga pokonania co najmniej $550 \mathrm{~m}$.

Tymczasem na tej samej linii kolejowej, w ramach tej samej modernizacji, została przebudowana stacja Warszawa Płudy wraz z realizacją nowego wiaduktu nad nią w ciągu ul. Klasyków. W tym przypadku zastosowano rozwiązanie w ocenie autorki artykułu wzorcowe. Na wiadukcie nad stacją zaprojektowano i zrealizowano zatoki autobusowe, z których czasem korzystają też użytkownicy taksówek i samochodów osobowych. Z przystanków schodzimy bądź zjeżdżamy windami bezpośrednio na perony - łatwo, szybko, wygodnie. Szkoda, że analogicznego rozwiązania nie przyjęto na stacji Mława Miasto (ryc. 24 i 25).

\section{Podsumowanie}

Mława to prężnie rozwijające się miasto. Zagospodarowanie wolnych działek budowlanych w części śródmiejskiej miasta wymaga szczególnego przeanalizowania i zastanowienia, zarówno pod kątem programu, jak i oprawy architektonicznej. Kształtujący się w mieście ciąg usługowy (centrum pasmowe) pomiędzy stacją kolejową a rejonem Starego Rynku wymagać będzie szczególnego, reprezentacyjnego zagospodarowania systemu przestrzeni publicznych i ogólnodostępnych, łączących przedpole stacji z rynkiem. Władze samorządowe, prowadzące konsekwentną politykę przestrzenną powinny docelowo uzyskać zakładane efekty. Wzmocnienia pasma centralnego na jego krańcach lokalnymi centrami handlowymi może okazać się pozytywne dla historycznych placów miejskich: Starego i 1 Maja (Zielony Rynek). Mogą one, zachowując unikatowe oraz lokalne funkcje handlowe, przekształcić się w kierunku przestrzeni reprezentacyjno-rekreacyjnych, z większym niż dotychczas programem gastronomicznym oraz z wyłączeniem części ich przestrzeni z ruchu kołowego.

Dużym problemem są inwestycje od miasta niezależne, częściowo niweczące kompleksowe plany miasta. Brak możliwości narzucenia swojej woli przez władze samorządowe takim jednostkom jak Polskie Koleje Państwowe czy zarządcy dróg, skutkuje w konsekwencji problemami funkcjonalnymi takimi jak w przypadku dostępności stacji Mława Miasto, nie wspominając o samej randze tej stacji. Sugestia autorki, by w czynie społecznym usunąć barierki na wiadukcie, rzucona oczywiście jako żart, jest wyrazem bezsilności w takich sytuacjach. Być może „władztwo planistyczne” gminy powinno zostać rozszerzone na podobne przypadki - aby to inwestor musiał uzgodnić z miastem swoje planowane działania, uzyskując dla nich akceptację samorządu, mającego kompleksową wizję rozwoju miasta. 


\section{Literatura}

Juszkiewicz R., 2004, Mława - jej dzieje (lata 1914-1939), Stacja Naukowa im. prof. dr hab. Stanisława Herbsta, Mława.

Kuncewicz A.,1929, Plany przeglądowe miast polskich, Politechnika Warszawska, Warszawa.

Mława,1885, [w:] F.Sulimierski, B. Chlebowski, W. Walewski (red.), Słownik geograficzny Królestwa Polskiego i innych krajów słowiańskich, t. 6: Malczyce - Netreba, Wyłącznym Nakładem Władysława Walewskiego, Druk „Wieku” Nowy Świat Nr 59, Warszawa, s. 528.

Ostaszewski J., 1934, Z dziejów mławskiego Mazowsza. Szkic historyczny, Mława.

Staszewski D.,1907, Mława. Opis historyczny, druk Fr. Karpińskiego, Elektoralna 14, Warszawa.

Pazyra S., 1959, Geneza i rozwój miast mazowieckich, Warszawa.

Zygner L., 2002, Mława - miasto pogranicza, Wydawnictwo: Inne, Ciechanów.

http://new.zawkrze.pl/index.php?option=com_content\&view=article\&id=78:ryshistoryczny-smlw-zawkrze\&catid=84\&showall=\&limitstart $=1 \&$ Itemid $=435$ 


\section{Movement of the Mława city center in the city's development history - the role of the rail- way station in the creation of the city center}

\section{ABSTRACT}

The aim of this paper is to present contemporary problems of development and functioning of the Mława city center, with particular emphasis on the history of the development and relocation of city center functions related to the trade tradition.

The original market-square from the end of the 15th century, was the centerpiece till the Second World War. Since the end of the 19th century, the center has grown westward. The second half of the twentieth century, it's the rapid development of the city center in the western part of the city.

The beginning of the 21st century it's the realization of large shopping centers, complementing the existing program of the center and strengthening its layout on the east-west axis.

The latest plans of the city administration are the construction of a new large-scale trade facility in the area of the Mława Miasto station, which uses the growing, urban-creating significance of this station. The second similar complex will be the retail center north-east of the market square. Once completed, they will become the distinct ends of the urban belt of the centre.

This article contains general suggestions for the proposed measures to strengthen, first of all, the arrangement of pedestrian links and representative spaces that can be placed within the center.

Key words: Mława, market square, Old Market Square, Wólka, Mława Miasto train station, town hall

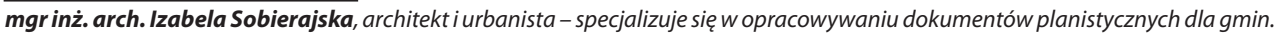
Asystent w Wyższej Szkole Ekologii i Zarządzania, ul. Olszewska 12, 00-792 Warszawa, e-mail: archisplan@archisplan.pl

Izabela Sobierajska, M. Ar., architect and urban planner - specializes in developing planning documents for municipalities. Assistant at the University of Ecology and Management, ul. Olszewska 12, 00-792 Warszawa, e-mail: archisplan@archisplan.pl

mgr inż. arch. Teresa Wyszyńska, architekt $i$ konserwator zabytków - specjalizuje się w dziedzinie ochrony i konserwacji zabytków. Asystent w Wyższej Szkole Ekologii i Zarządzania, ul. Olszewska 12, 00-792 Warszawa, e-mail: tma.wyszynska@gmail.com

Teresa Wyszyńska, M. Ar., architect and conservator of monuments - specializes in the protection and preservation of monuments. Assistant at the University of Ecology and Management, ul. Olszewska 12, 00-792 Warszawa, e-mail: tma.wyszynska@gmail.com 